\title{
DIVERSIFIKASI PRODUK OLAHAN BUAH KELAPA PADA KELOMPOK TANI DESA PULAU PANGGUNG KABUPATEN KAUR
}

\section{DIVERSIFICATION OF COCONUT PRODUCTS ON FARMER GROUP OF PULAU PANGGUNG KAUR REGENCY}

\author{
Oleh: \\ Deni Agus Triawan, Charles Banon, Morina Adfa \\ Jurusan Kimia Fakultas Matematika dan Ilmu Pengetahuan Alam Universitas Bengkulu \\ Email: deni.agustriawan@unib.ac.id
}

\begin{abstract}
The aim of this community service to give information about the productivity of coconuts that are beneficial and of high economic value in the Farmers Group Pulau Panggung, Kaur Regency. Several methods including lectures, discussions, demonstrations, direct practice and observation were used. The results of this activity can be seen from the level of community participation in the activities indicated by the presence of 25 participants. In addition, the results of the activities carried out have been made of coconut products by the form of virgin coconut oil (VCO), nata de coco and coconut water fermentation drinks. The skills of participants in the manufacture of these products are conveyed by direct practice methods with the guidance of the speaker. Analysis of the benefits of coconut products is based on capital (raw materials) and products produced. The estimated selling price of the product produced from processed 20 coconuts is Rp. 7500 (nata de coco) and Rp. 600,000 (VCO). The advantage of the product made is that it can increase profits by Rp. 547,500 (Rp. 607,500 - Rp. 60,000).
\end{abstract}

Keywords: diversification, productivity, coconut products, VCO, Kaur Regency

\section{PENDAHULUAN}

Kelapa (Cocos nucifera) mempunyai peran yang cukup penting dalam kehidupan masyarakat Indonesia, karena kelapa banyak dibudidayakan oleh sebagian besar masyarakat sebagai tanaman tahunan yang mempunyai nilai ekonomis dan sosial. Kelapa juga sering disebut sebagai pohon kehidupan (tree of life) dan pohon surga (a heavenly tree) karena hampir semua bagian tanaman dapat dimanfaatkan untuk kehidupan (Andi, N.A, 2005). Komoditas kelapa bagi masyarakat Indonesia memiliki peranan multiguna dan strategis, karena terkait dengan berbagai segi kehidupan. Kabupaten Kaur merupakan salah satu wilayah di Provinsi Bengkulu dengan potensi kelapa cukup tinggi dengan produksi mencapai 7000 buah perbulan (Kecamatan Luas). Pemanfaatan buah kelapa oleh masyarakat Kabupaten Kaur umumnya saat ini terbatas pada penjualan ke tengkulak (toke) dengan harga Rp.3000-Rp.3500 per buah. Tingginya produktivitas buah kelapa di Kabupaten Kaur berpotensi menjadi sektor unggulan Kabupaten terutama dengan membuat beberapa produk turunan buah kelapa. 


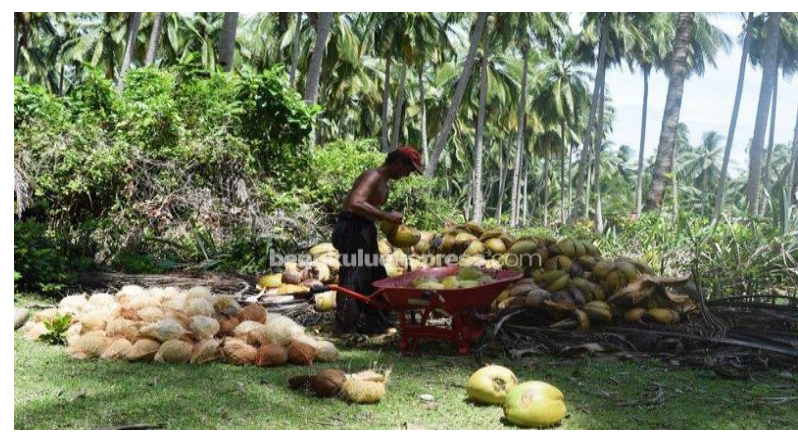

Gambar 1. Panen Kelapa di Kabupaten Kaur (Sumber : Bengkulu Ekspress.com)

Dari segi peranan ekonomi tanaman kelapa, belum mencapai tingkat yang optimal terutama apabila dilihat dari segi pendapatan petani. Pendapatan usahatani kelapa yang dikelola petani belum mampu menunjang kehidupan keluarga petani secara layak, sehingga petani kelapa secara nasional masih hidup di bawah garis kemiskinan. Suatu kenyataan dimana proporsi pendapatan petani hanya $20 \%$ dari total pendapatan keluarga. Diversifikasi usahatani secara vertikal berarti menganekaragamkan produk usahatani secara efisien disertai dengan peningkatan mutu sehingga produk lebih kompetitif dan memberikan nilai tambah (Tarigans, 2005).

Penganekaragaman produk olahan usahatani yang berpeluang memberikan tambahan pendapatan antaranya adalah pengolahan daging buah kelapa menjadi Virgin Coconut Oil (VCO) dengan metode pemancingan (Oseni et al, 2017), penggaraman (Susilowati, 2009), maupun enzim (Witono et al, 2007). Selain itu, pengolahan buah kelapa juga dapat dilakukan pada air kelapa menjadi nata de coco (Gayathry , 2015) dan pembuatan susu fermentasi dari santan kelapa dengan skala home industry (Khoiriyah, 2013). Pemilihan produk ini diterapkan berdasarkan fasilitas pengolahan yang sederhana, mudah dilakukan, terjangkau dan memiliki peluang pemasaran yang strategis. Pengembangan produk olahan ini diharapkan mampu memberikan kontribusi pendapatan masyarakat sekitar (Kabupaten Kaur pada umumnya) dan mengubah pernyataan bahwa sektor kelapa yang dikelola petani belum mampu menunjang pendapatan petani.

\section{METODE PENGABDIAN}

Kegiatan diawali dengan penyampaian informasi, diskusi dan tanya jawab dengan tujuan meningkatkan pemahaman masyarakat tentang produk turunan dari buah kelapa diantaranya VCO, nata de coco dan susu serta kegunaan dari jenis produk tersebut dan nilai jualnya. Kegiatan ini dimulai dengan ceramah dan diskusi tentang cara dan peralatan pembuatan VCO, nata de coco dan susu melalui pembagian handout pada kelompok mitra. Setelah mitra memahami teori cara pembuatan produk buah kelapa tersebut, kegiatan dilanjutkan dengan pelatihan secara intensif..

Selanjutnya dilakukan pelatihan pembuatan produk sebagai berikut:

1. Pembuatan VCO dengan teknik pemancingan secara detail adalah sebagai berikut: kelapa diparut, ditambahkan air matang hangat semaksimal mungkin, kemudian diperas hingga menghasilkan santan. Santan yang diperoleh ditempatkan pada wadah yang bersih, steril dan transparan lalu didiamkan selama 1 jam hingga terbentuk krim santan. Pisahkan krim santan dalam wadah tertutup yang bersih, steril dan transparan. Kemudian tambahkan minyak VCO pemancing dengan perbandingan minyak VCO pemancing: krim santan adalah 1:20. Aduk secara perlahan hingga campuran merata, 
kemudian diamkan selama 10-12 jam dalam kondisi wadah tertutup dan tempat kering. Pisahkan minyak VCO dari krim santan dengan metode penyaringan menggunakan kertas saring yang steril dan bersih (Asy'ari, M \& Cahyono, B, 2006).

2. Pembuatan nata de coco dilakukan dengan cara sebagai berikut: rebus air kelapa dalam panci selama 3 mnit (dalam keadaan mendidih). Kemudian tuangkan gula pasir ke dalam air kelapa yang mendidih. Tunggu air kelapa menjadi dingin dan tambahkan asam cuka sekitar $10 \mathrm{~mL}$ ke dalam larutan air kelapa. Tambahkan starter bakteri Acetobacter Xylinum kedalam larutan, aduk-aduk hingga merata. Tuangkan larutan ke dalam loyang atau baskom. Tutup bahan nata de coco dengan kertas atau koran dan ikat dengan tali. Simpan dan letakkan di dalam rak yang stabil dan tidak mudah goyang. Tunggu hingga kurang lenih 14 hari agar menjadi nata. Setelah nata de coco jadi, cuci dengan air dan rendam hingga 2 hari. Nata yang akan dikonsumsi hendaknya direbus agar mengenyal.

3. Pembuatan minuman fermentasi air kelapa dilakukan karena air kelapa mempunyai asam amino yang relatif baik dan bernilai gizi tinggi (Yanuar, T, 1992). Proses fermentasi ini dilakukan dengan bantuan bakteri Lactobacillus bulgaricus dan Streptococus thermophillus. Perbandingan dari kedua mikroorganisme ini akan mempengaruhi kecepatan fermentasi, dan diharapkan perbandingannya dapat mentyebabkan tercapainya $\mathrm{pH}$ optimal, yaitu $\mathrm{pH}$ antara 4,2-4,4. Proses fermentasi dilakukan selama 24 jam pada suhu $38^{\circ} \mathrm{C}$. Setelah susu fermentasi jadi, simpan pada lemari pendingin dan bertahan selama 7 hari.

\section{HASIL DAN PEMBAHASAN}

Kegiatan ini dilaksanakan dengan tujuan untuk memberikan informasi tentang produktivitas buah kelapa yang bermanfaat dan bernilai ekonomi tinggi di Kelompok Tani Desa Pulau Panggung Kabupaten Kaur. Tujuan tersebut dapat dicapai melalui beberapa metode diantaranya ceramah, diskusi, demonstrasi, praktek langsung serta observasi. Metode ceramah digunakan dalam proses penyampaian materi pelatihan dengan tujuan meningkatkan pemahaman masyarakat tentang produk turunan dari buah kelapa diantaranya VCO, nata de coco dan minuman fermentasi sari kelapa serta kegunaan dari jenis produk tersebut dan nilai jualnya. Kegiatan ini dimulai dengan ceramah dan diskusi tentang cara dan peralatan pembuatan VCO, nata de coco dan susu melalui pembagian handout pada kelompok mitra. Setelah mitra memahami teori cara pembuatan produk buah kelapa tersebut, kegiatan dilanjutkan dengan pelatihan secara intensif. Pelaksanaan kegiatan ini dapat diketahui dari tingkat partisipasi masyarakat dalam kegiatan yang ditunjukkan dengan kehadiran sebanyak 25 orang peserta pelatihan (terlampir dalam daftar hadir) dalam kegiatan pemaparan, diskusi dan Tanya jawab di rumah salah satu warga (Gambar 2).
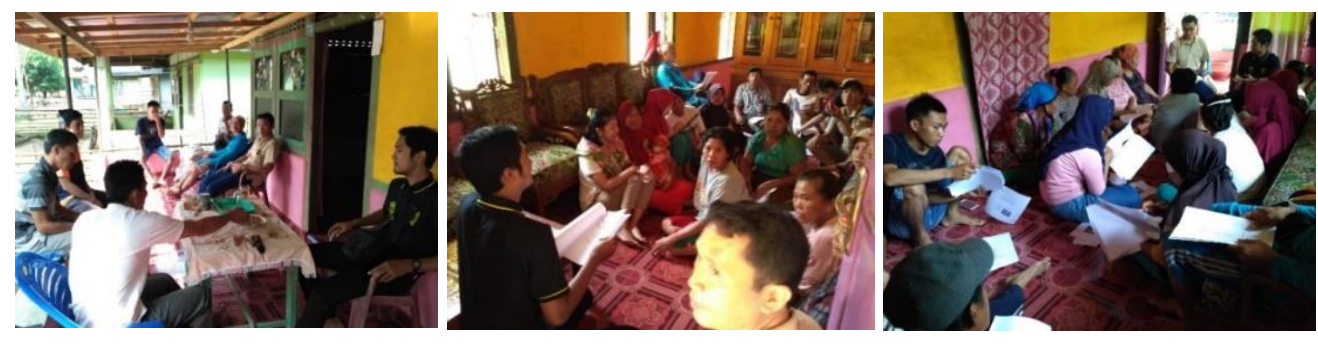
Gambar 2. Proses penyampaian informasi, diskusi dan Tanya jawab

Disamping penyampaian informasi, metode ceramah ini juga dimaksudkan memberikan motivasi kepada masyarakat untuk dapat memulai dan mendalami usaha tentang pengolahan buah kelapa dengan berbagai keunggulan dan kelebihan mengingat potensi kelapa di Kabupaten Kaur cukup tinggi. Metode diskusi digunakan sebagai media komunikasi saat pelatihan berlangsung sehingga terjadi komunikasi dua arah antara pemateri dan masyarakat. Setelah kegiatan penyampaian informasi selesai, kegiatan berlanjut dengan persiapan bahan pelatihan oleh tim pengabdi dibantu oleh masyarakat. Persiapan bahan yang dimaksud seperti santan kelapa untuk pembuatan minyak kelapa murni (Gambar 3). Kelapa diperoleh dari kebun Bapak Dahri selaku Ketua Kelompok Tani Desa Pulau Panggung.

Selanjutnya, dilakukan demonstrasi digunakan dalam proses memberikan contoh dalam setiap pelatihan, sehingga memberikan kemudahan kepada masyarakat dalam memahami materi yang disampaikan. Demonstrasi dilakukan melalui percontohan pembuatan nata de coco, pembuatan VCO dan minuman fermentasi air kelapa (Gambar 4).

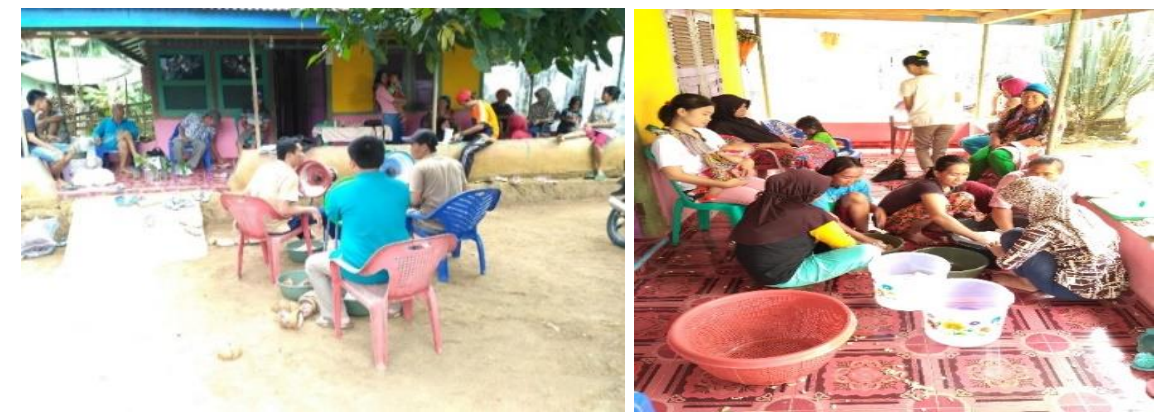

Gambar 3. Persiapan bahan dan alat pelatihan

Metode praktik langsung digunakan untuk mengaplikasikan materi yang telah didapatkan melalui penyampaian informasi maupun demonstrasi, tentunya dengan bimbingan pemateri. Kegiatan ini dapat diikuti dengan baik oleh masyarakat dan tingkat antusias masyarakat cukup tinggi yang ditunjukkan bahwa hampir semua anggota pelatihan mencoba dan memahami seluruh rangkaian proses pelatihan (Gambar 5). Metode observasi dilakukan untuk mengamati kemampuan masyarakat baik selama proses pelatihan maupun sesudah pelatihan. Pengamatan pada saat pelatihan dilakukan untuk mengetahui kemampuan masyarakat dalam menerapkan ipteks yang sudah dijelaskan sebelumnya. Pengamatan sesudah pelatihan ditujukan untuk mengetahui dampak dari pelatihan yang telah dilaksanakan terkait dengan kemajuan tingkat produktivitas masyarakat.
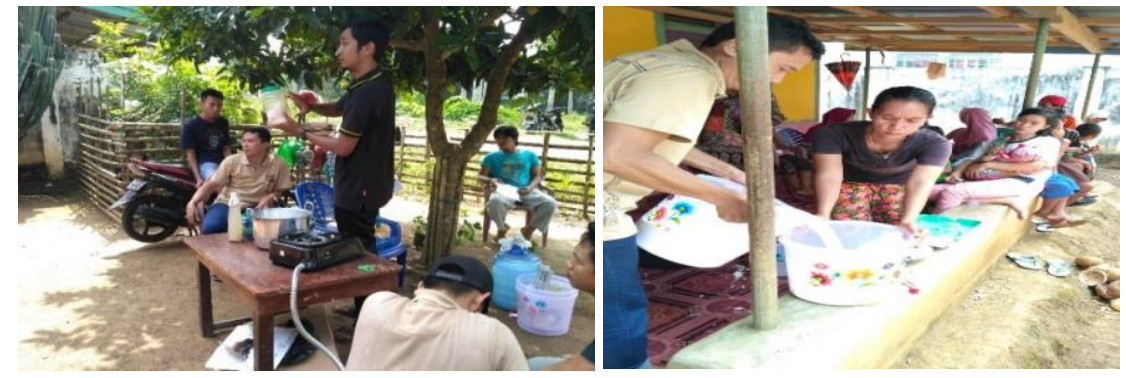
Gambar 4. Proses demonstrasi oleh tim pengabdi

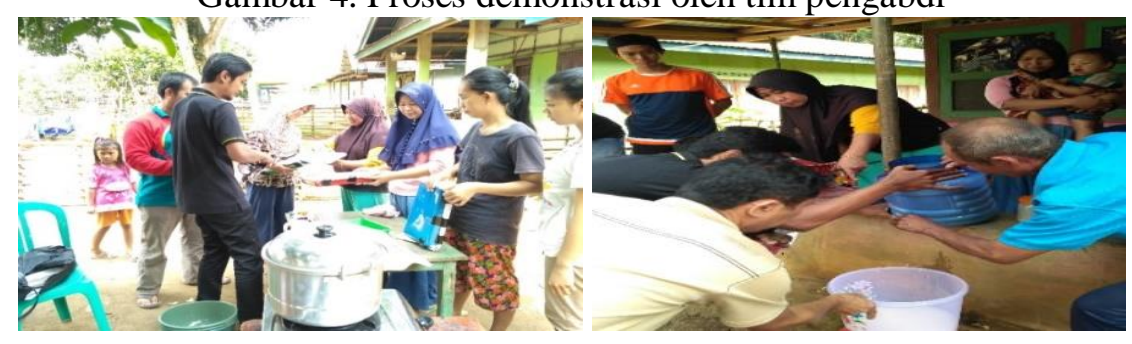

Gambar 5. Praktek yang dilakukan oleh masyarakat

Beberapa pertanyaan muncul pada saat kegiatan pelatihan pembuatan nata de coco diantaranya faktor apa saja yang menentukan keberhasilan pembuatan nata de coco. Keberhasilan pembuatan nata de coco ditentukan oleh banyak hal, diantaranya sebagai berikut :

a. Penggunaan media/wadah yang steril

b. Pemberian nutrisi yang cukup bagi bakteri

c. Tutup wadah dengan kertas/kain agar tetap ada udara yang masuk

d. Letakkan wadah pada keadaan statis

Sedangkan pada pembuatan VCO dan minuman fermentasi air kelapa tidak begitu banyak pertanyaan karena prosesnya yang cukup mudah. Pada pembuatan VCO, masyarakat dapat cepat memahami bahwa prinsip dari metode pemancingan pada saat pembuatan VCO adalah untuk mengeluarkan minyak dalam santan dengan bantuan minya VCO yang telah ada. Setelah itu, proses pendiaman dilakukan untuk mendapatkan beberapa lapisan yang terdiri dari air, blondo dan minyak VCO sebelum dipisahkan. Hasil akhir dari kegiatan adalah telah dibuatnya produk olahan buah kelapa berupa minyak kelapa murni (VCO), nata de coco dan minuman fermentasi air kelapa. Keterampilan peserta dalam pembuatan produk tersebut disampaikan dengan metode praktik langsung dengan bimbingan pemateri. Beberapa peralatan yang diperbantukan oleh pelaksana kegiatan kepada masyarakat berupa alat pemisah minyak dari emulsi santan kelapa, dan peralatan pembuatan nata de coco.
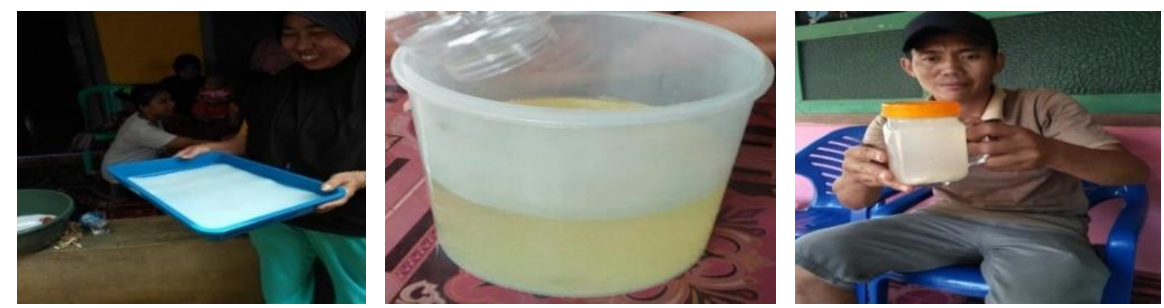

Gambar 6. Produk akhir yang telah dibuat

\section{Analisis keuntungan dari kegiatan diversivikasi produk}

Analisis keuntungan dari pengolahan buah kelapa dilakukan berdasarkan modal (bahan baku) dan produk yang dihasilkan. Jenis usaha yang dilakukan adalah industry rumah tangga sehingga tidak memerlukan lokasi/lahan usaha, serta peralatan yang digunakan dalam proses produksi juga peralatan sederhana yang sudah disiapkan oleh tim pengabdian. Produk yang potensial dibuat (berdasarkan konsep proposal kegiatan) adalah nata de coco, minyak kelapa murni (VCO) dan minuman fermentasi. Dari 20 butik kelapa, perkiraan nata de coco yang dihasilkan sebanyak $5 \mathrm{~kg}$ nata de coco lembaran dengan harga 
jual Rp. 1500/kg. Sedangkan VCO bersih yang dihasilkan sebanyak \pm 4 liter dengan harga jual Rp.150.000/liter (sumber: shopee.id). Harga jual kelapa butiran di lokasi saat ini Rp.3000/butir, sehingga total harga jual 20 kelapa sekitar Rp.60.000. Prakiraan harga jual produk yang dihasilkan dari olahan 20 butir kelapa adalah nata de coco Rp.7500 dan VCO sebesar Rp.600.000. Keunggulan produk yang dibuat adalah dapat meningkatkan keuntungan sebesar Rp.547.500 (Rp.607.500-Rp.60.000).

\section{KESIMPULAN DAN SARAN}

\section{Kesimpulan}

Diversifikasi produk olahan kelapa melalui pembuatan VCO, nata de coco dan minuman fermentasi dari air kelapa di Kelompok Tani Desa Pulau Panggung Kabupaten Kaur telah dilaksanakan dengan keberhasilan yang baik dibuktikan dengan tingginya partisipasi anggota mitra sebanyak 25 orang. Selain itu, kegiatan dapat diikuti oleh semua anggota mitra dengan tiga metode yaitu ceramah, demonstrasi dan praktek. Metode tersebut dinilai efektif dalam program ini dilihat dari tingkat keberhasilan masyarakat dalam menciptakan produk yang dimaksud dalam kegiatan. Analisis keuntungan dari pengolahan buah kelapa dilakukan berdasarkan modal (bahan baku) dan produk yang dihasilkan. Prakiraan harga jual produk yang dihasilkan dari olahan 20 butir kelapa adalah nata de coco Rp.7500 dan VCO sebesar Rp.600.000. Keunggulan produk yang dibuat adalah dapat meningkatkan keuntungan sebesar Rp.547.500 (Rp.607.500-Rp.60.000). Beberapa peralatan yang diperbantukan oleh pelaksana kegiatan kepada masyarakat berupa alat pemisah minyak dari emulsi santan kelapa, dan peralatan pembuatan nata de coco.

\section{Saran}

Perlu dilanjutkan pelatihan pembuatan diversifikasi produk lain seperti pengolahan tempurung kelapa menjadi asap cair dana rang aktif serta pelatihan proses pemasaran misalnya dengan bantuan sistem elektronik (berbasis web) melalui sistem grafis.

\section{DAFTAR PUSTAKA}

Andi, N, A., 2005, Virgin Coconut Oil Minyak Penakluk Aneka Penyakit, Tangerang : PT Agro Media Pustaka.

Asy'ari, M., Cahyono, B., 2006, Pra-Standarisasi : Produk dan Analisis Minyak Virgin Coconut Oil (VCO), J.Kim.Sains \& Apl. Vol.IX, No.3 : 74 - 80.

Gayathry, G., 2015, Production of Nata de Coco - a Natural Dietary Fibre Product from Mature Coconut Water using Gluconacetobacter xylinum (sju-1). Intl.J.Food.Ferment.Technol. 5(2):231-235.

Khoiriyah, L, K., Fatchiyah, 2013, Karakter Biokimia dan Profil Protein Yoghurt Kambing PE Difermentasi Bakteri Asam Laktat (BAL). jurnal Exp.Life Sci, Vol.3, No.1.

Oseni, N, T., Fernando, W., Coorey, R., Gold, I., Jayasen, V., 2017, Effect of Extraction Technique on The Quality of Coconut Oil., Academic Journal. Vol.11(3):58-66.

Susilowati, 2009, Pembuatan Virgin Coconut Oil dengan Metode Penggaraman, Jurnal Teknik Kimia Vol.3, No.2 : 246 - 251.

Tarigans, D, D., 2005, Diversifikasi Usahatani Kelapa Sebagai Upaya Untuk Meningkatkan Pendapatan Petani, Perspektif, Vol.4 No 2:71-78.

Witono, Y., Aulanni'am, Subagio, A., Widjanarko, S, B., 2007, Ekstraksi Virgin Coconut Oil Secara Enzimatis Menggunakan Protease dari Tanaman Biduri. Agritech. Vol.27, No.3 : $100-106$. 
Dharma Raflesia Unib Tahun XVII, Nomor 1 Juni 201940

Yanuar, T., 1992, Studi Mutu Yoghurt Santan Kelapa Selama Penyimpanan. Bogor : IPB. 